\title{
Schwann Cell Apoptosis during Normal Development and after Axonal Degeneration Induced by Neurotoxins in the Chick Embryo
}

\author{
Dolors Ciutat, ${ }^{1}$ Jordi Calderó, ${ }^{1}$ Ronald W. Oppenheim, ${ }^{2}$ and Josep E. Esquerda1 \\ 1Unitat de Neurobiologia Cel.lular, Departament de Ciències Mèdiques Bàsiques, Facultat de Medicina, Universitat de \\ Lleida, 25198 Lleida, Catalonia, Spain, and 2Department of Neurobiology and Anatomy and Neuroscience Program, \\ Bowman Gray School of Medicine, Wake Forest University, Winston-Salem, North Carolina 27157
}

In the present work, we show that chick embryo Schwann cells die by apoptosis both during normal development and after axonal degeneration induced by neurotoxin treatment. Schwann cell apoptosis during development takes place during a period roughly coincidental with normally occurring motoneuron death. Administration of NMDA to chick embryos on embryonic day 7 induces extensive excitotoxic motoneuronal damage in the spinal cord without any apparent effects on neurons in the dorsal root ganglia (DRG). The death of Schwann cells in ventral nerve roots after NMDA treatment causes degenerative changes that display ultrastructural features of apoptosis and exhibit in situ detectable DNA fragmentation. By contrast, NMDA treatment does not increase the death of Schwann cells in dorsal nerve roots. In situ detection of DNA fragmentation in combination with the avian Schwann cell marker 1E8 antibody demonstrates that dying cells in ventral nerve roots are in the Schwann cell lineage. Administration of cycloheximide does not prevent the toxic effects of NMDA on motoneurons, but dramatically reduces the number of pyknotic Schwann cells and DNA fragmentation profiles in the ventral nerve roots. In ovo administration of various tissue extracts (muscle, brain, and spinal cord) from the chick embryo or of the motoneuron conditioned medium fails to prevent Schwann cell apoptosis in NMDA-treated embryos. Intramuscular administration of the snake toxin $\beta$-bungarotoxin produces a massive death of both lateral motor column motoneurons and DRG neurons, resulting in a substantial increase in the number of pyknotic Schwann cells in both ventral and dorsal nerve roots. It is concluded that during development, axonal-derived trophic signals are involved in the regulation of Schwann cell survival in peripheral nerves.

Key words: Schwann cells; apoptosis; peripheral nerves; development; excitotoxicity; $\beta$-bungarotoxin; chick embryo
During development of the nervous system, most neuronal populations undergo a process of programmed cell death (for reviews, see Cowan et al., 1984; Oppenheim, 1991). The most conspicuous consequence of this process is the attainment of an appropriate adjustment between an excess number of initially generated neuronal cells to the precise requirements for adequate connectivity. It is generally considered that redundant neurons die by apoptosis because they do not receive suitable extracellular signals for their survival (e.g., neurotrophic factors) (for reviews, see Barde, 1984; Oppenheim, 1989; Barde, 1994; Davis, 1994; Lindsay et al., 1994). During the past few years, cell death has been investigated extensively in neuronal cells, but less information is available about the role of programmed cell death during the development of glial cells.

Normal cell death has been detected in oligodendrocytes in the developing optic nerve (Barres et al., 1992a,b; Raff et al., 1993), and this death seems to be regulated by trophic factors derived from axons (Barres et al., 1992b; Raff et al., 1993; Barres et al., 1994). In this case, programmed cell death leads to an accurate matching

\footnotetext{
Received Jan. 29, 1996; revised March 26, 1996; accepted March 29, 1996.

This study was supported by the Ministerio de Educación y Ciencia (Spain, Grant PB93-0642), a grant from the Ajuntament de Lleida, and National Institutes of Health Grant NS 20402 (R.W.O.). We gratefully acknowledge Dr. Nancy Ratner for providing the $1 \mathrm{E} 8$ antibody. We are also indebted to Dr. Rosa M. Soler for providing motoneuron-conditioned medium, and to Anna Naco, Anna Martínez, and Esther Castan for skillful technical assistance. We thank COPAGA (Lleida) for supplying the eggs used in this work.

Correspondence should be addressed to Josep E. Esquerda, Unitat de Neurobiologia Cel.lular, Departament de Ciències Mèdiques Bàsiques, Facultat de Medicina, Universitat de Lleida, Avinguda Rovira Roure 44, 25198 Lleida, Catalonia, Spain. Copyright (C) 1996 Society for Neuroscience $0270-6474 / 96 / 163979-12 \$ 05.00 / 0$
}

between the number of axons and myelinating cells (Barres et al., $1992 \mathrm{~b})$. Astrocytes also undergo programmed cell death during normal development of the rat cerebellum (Krueger et al., 1995). It has long been known that during the development of the peripheral nervous system, Schwann cells send out processes that surround large groups of growing axons, but as maturation occurs, they delimitate progressively smaller axon bundles until each Schwann cell ensheaths a single myelinated axon (Webster et al., 1973; Peters et al., 1976; Bray et al., 1981; Jacobson, 1991). This process by which myelinated axons become segregated from neighbors does not take place in unmyelinated fibers, in which several axons persistently share the same Schwann cell (Ochoa, 1976). Adjustment of the final axon-glia ratio in myelinated fibers involves the death of both redundant axons and Schwann cells (Aguayo et al., 1973; Berthold, 1973; Chu-Wang and Oppenheim, 1978). Consistent with this, neural crest-derived Schwann cell precursors cannot be maintained in vitro in the absence of specific putative survival factors contained in neuronal conditioned medium (Jessen et al., 1994). Furthermore, it has also been reported that fibroblast growth factors (FGFs) and insulin-like growth factors (IGFs) added to the medium rescue $100 \%$ of Schwann cell precursors from death (Gavrilovic et al., 1995). It remains to be demonstrated, however, whether these factors are present in the appropriate location and period of time within developing nerves in vivo. Additionally, it should be taken into account that one of these factors, FGF2, has only a very transient effect $(1 \mathrm{~d})$ in rescuing Schwann cells in vitro, as reported by Dong et al. (1995). Recent data indicate that the $\beta$ forms of Neu differentiation factor (NDF or neuregulins), which are present in developing peripheral 
sensory and motor neurons, regulate the differentiation and survival of rat Schwann cell precursors by acting through specific NDF receptors (ErbB family) (Marchionni et al., 1993; Dong et al., 1995; Meyer and Birchmeier, 1995). Additionally, one member of this gene family, glial growth factor (GGF), prevents axotomy-induced Schwann cell death at the postnatal rat neuromuscular junction in vivo (Trachtenberg and Thompson, 1996). To investigate further the normal physiological mechanisms that control embryonic Schwann cell differentiation and death, we have employed an avian model in which in vivo experiments can be performed.

Here, we report that during chick embryo development, significant numbers of Schwann cells are normally eliminated by apoptosis. In motor nerves, this process occurs during a period roughly coincidental with normally occurring motoneuron death.
Moreover, experimentally induced axonal (sensory or motor) degeneration results in a dramatic increase in Schwann apoptosis, providing in vivo evidence for the regulation of Schwann cell survival by axonal-derived signals. This provides a new in vivo experimental paradigm in which the regulation of Schwann cell apoptosis can be investigated.

\section{MATERIALS AND METHODS}

Eggs and embryos. Fertilized chicken eggs (Arbor Acres strain) were obtained from a local supplier (COPAGA) and were incubated in a forceddraft, rotating incubator $\left(37.5^{\circ} \mathrm{C}\right.$ and $60 \%$ relative humidity) until the desired experimental age. Drugs, tissue extracts, or conditioned medium was administered through a small window in the shell that exposed the vascularized chorioallantoic membrane (CAM), and they (100-150 $\mu$ l volumes) were dropped directly onto the CAM. The window was sealed with a piece of
Figure 1. Double-fluorescent labeling to demonstrate immunoreactivity to $1 \mathrm{E} 8$ antibody and DNA fragmentation in ventral nerve roots from E7.5 chick embryos. Confocal laser-scanning micrographs from cryostat sections in which 1E8-positive labeling (red) shows that some Schwann cells (arrow) contain fragmented DNA (green) in embryos treated with saline $(a)$ and $12 \mathrm{hr}$ after NMDA treatment $(b, c)$. Note that the number of dying Schwann cells is substantially increased after NMDA treatment; $a r$ rowheads indicate 1E8-positive cells that contain negative TUNEL nuclear profiles. Scale bars: $a, b, 20 \mu \mathrm{m} ; c, 10 \mu \mathrm{m}$.
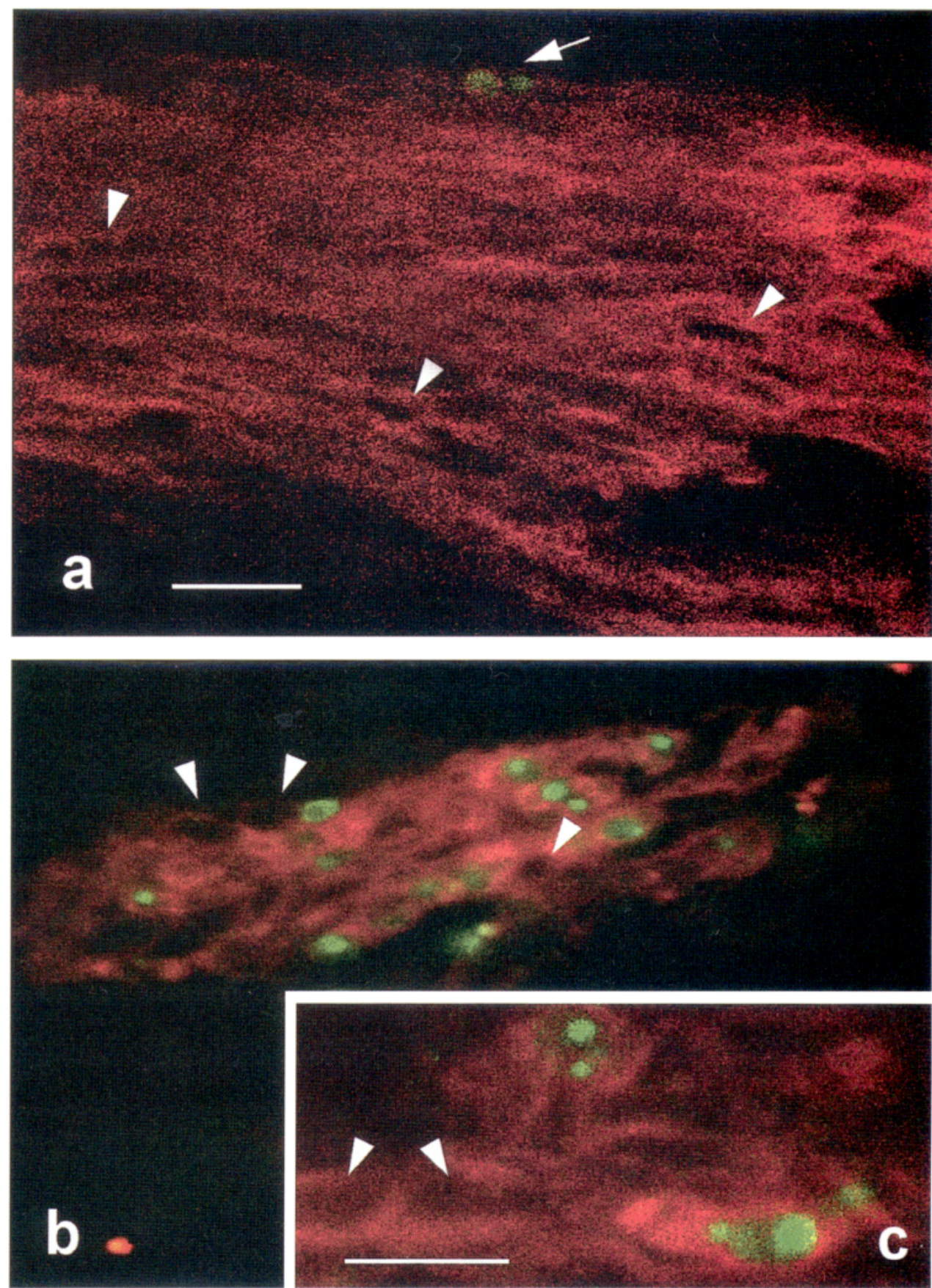
adhesive tapc, and the cggs were returncd to an incubator where they remained unturned until the embryos were killed.

Preparation of tissue extracts and motoneuron conditioned medium $(M C M)$. Brain extract (BEX), spinal cord extract (SCEX), and muscle (from the limbs) extract (MEX) were prepared from tissues obtained from cither embryonic day 9-10 (E9-10) or El6 chick embryos. Immediately after dissection, tissues were frozen in liquid nitrogen and stored at $-80^{\circ} \mathrm{C}$. Samples were thawed on ice and homogenized using a Polytron apparatus at setting 4 for $2 \times 60 \mathrm{sec}$ in $2-3 \mathrm{vol}$ of PBS $(137 \mathrm{mM} \mathrm{NaCl}, 2.7$

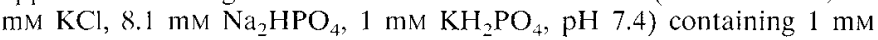
EDTA (Sigma, Saint Louis, MO), $1 \mathrm{~mm}$ benzamidine (Sigma), $1 \mathrm{~mm}$ $N$-ethylmaleimide (Sigma), and $0.1 \mathrm{~mm}$ phenylmethylsulfonyl fluoride (Sigma) to minimize proteolysis. Homogenates were centrifuged at $25,000 \times g$ for $30 \mathrm{~min}$, and the resulting supernatant (crude extract) was dialyzed overnight. Protein concentrations were determined according to Lowry et al. (1951). Crude extracts were stored in $1-2 \mathrm{ml}$ aliquots at $-80^{\circ} \mathrm{C}$ no longer than I week before use. MCM was obtained from primary cultures of motoneurons purified from E5.5 chick embryos and plated for $6 \mathrm{~d}$. The purification and culture of motoneurons was performed according to Comella et al. (1994).

Pharmacological experiments. In one set of experiments, E7 embryos were treated with a single dose of NMDA (Sigma). Other E7 embryos were treated with $2 \mu \mathrm{g}$ of cycloheximide (CHX) (Boehringer Mannheim, Mannheim, Germany) every $4 \mathrm{hr}$. In these embryos $1 \mathrm{mg}$ of NMDA was applied $2 \mathrm{hr}$ after the first dose of CHX. For administration, drugs were dissolved in saline solution and sterilized by ultrafiltration. Embryos were killed at different intervals between $30 \mathrm{~min}$ and $12 \mathrm{hr}$ after NMDA treatment. Some embryos were treated on both E6 and E7 with either 150 $\mu \mathrm{g}$ of single tissue extracts (MEX, BEX, or SCEX) or $250 \mu \mathrm{g}$ of MCM. The same embryos received a single dose of $1 \mathrm{mg}$ of NMDA on E7 and were killed $12 \mathrm{hr}$ later. In all the experiments, embryos injected with identical volumes of physiological saline were used as controls.

In one group of embryos, $1 \mu \mathrm{l}$ of either $\beta$-bungarotoxin $(\beta$-Bgtx, 100 ng) from Bungarus multicinctus (Sigma) or saline was administered on E7 by intramuscular injection into the ventral muscle mass of the right leg. Injections were performed using pulled-glass capillary tubes attached to a $10 \mu \mathrm{l}$ Hamilton microsyringe. Legs were exposed through a small incision in a nonvascularized area of the CAM and stabilized with fine hair loops. The embryos were killed $12 \mathrm{hr}$ after the neurotoxin injection.

Histology and cell counts. Embryos were staged according to Hamburger and Hamilton (1951). For light microscopy, embryos were fixed in Carnoy's fluid, embedded in paraffin, scrially sectioned at $8 \mu \mathrm{m}$, and stained with thionin. In camera lucida drawings, all normal nuclcar profiles and all pyknotic cells present at the L3 dorsal and ventral roots were counted in alternate serial sections using a $60 \times$ or $100 \times$ oilimmersion objective. At this magnification the discrimination between pyknotic cells and mitotic figures can be distinguished easily. The criteria for identifying pyknotic cells were the same as those described by Clarke and Oppenheim (1995). Results were statistically analyzed by means of Student's $t$ test.

For retrograde labeling of axons in ventral and dorsal root ncrves as well as labeling of cell bodies of motor and sensory neurons, embryos were fixed by immersion in phosphate-buffered $4 \%$ paraformaldehyde, $\mathrm{pH}$ 7.1. A small crystal of dye $1^{\prime}, 1$-dioctadecyl-3,3,3',3'-tetramethyl lindocarbocyanine perchlorate (DiI) (Molecular Probes, Eugene, OR) was applied onto the dissected spinal nerves in the lumbosacral region. Embryos were incubated in the same fixalive at $37^{\circ} \mathrm{C}$ for $48-72 \mathrm{hr}$. Selected tissue picces were embedded in agar, and transverse sections $(100 \mu \mathrm{m})$ were obtained using a vibratome and mounted in slides with glycerol-PBS. Samples were observed in a confocal-laser scanning microscope Zeiss LSM-310 (Zeiss, Oberkochen, Germany) and viewed after excitation with a $543 \mathrm{~nm}$ Helium/Neon laser.

For electron microscopy, embryos were dissected to obtain thick slices of lumbar spinal cord that were fixed by immersion in $2.5 \%$ glutaraldehyde in $0.1 \mathrm{M}$ phosphate buffer, $\mathrm{pH} 7.4$, for $2 \mathrm{hr}$ at $4^{\circ} \mathrm{C}$. After washing with phosphate buffer, the slices of spinal cord were sectioned further using a vibratome to obtain transverse sections of $\sim 400 \mu \mathrm{m}$ in thickness that were postfixed in $1 \%$ osmium tetroxide for $2 \mathrm{hr}$, dehydrated, and embedded in Durcupan ACM (Fluka, Buchs, Switzerland). Ultrathin sections were obtained from selected areas containing ventral or dorsal roots from the lumbosacral enlargement, which were collected on copper grids, counterstained with uranyl acetate and lead citrate, and observed with a Zciss EM 910 electron microscope.

Cell-death labeling and immunocytochemistry. For in situ demonstration of DNA fragmentation, we performed terminal deoxynucleotidyl transferase-mediated dUTP-digoxigenin nick-end labeling (TUNEL) (Gavrieli et al., 1992). Embryos were fixed in $4 \%$ paraformaldehyde in 0.1

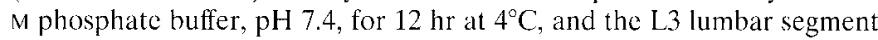
was dissected out and processed for paraffin embedding. Eightmicrometer-thick sections were mounted in Vectabond-coated (Vector Laboratories, Burlingame, CA) slides, deparaffined, and processed according to the instructions of the manufacturer for the ApopTag kit (Oncor, Gaithersburg, MD) using the peroxidase procedure.

Specific immunolabeling of Schwann cells was performed by means of the 1E8 monoclonal antibody (a generous gift from Nancy Ratner, University of Cincinnati Medical School), which recognizes chick $P_{0}$ protein that is present in both early nonmyclinating and mature Schwann cells (Bhattacharyya et al., 1991). Embryos were fixed overnight in cold $4 \%$ paraformaldehyde in $0.1 \mathrm{M}$ phosphate buffer, $\mathrm{pH}$ 7.4. After cryoprotection with several changes of $20 \%$ sucrose in 0.1 PBS, embryos were embedded in Tissue-Tek OCT embedding medium (Miles, Elkhart, IN) and frozen. Transverse cryostat sections (20 $\mu \mathrm{m}$ thick) were obtained and mounted in Vectabond-coated slides. After blocking endogenous peroxidase with $1 \%$ hydrogen peroxide in PBS for 45 min and unspecific binding with $10 \%$ normal goat serum (NGS) (Sigmit) in PBS for $1 \mathrm{hr}$, sections were incubated for $24 \mathrm{hr}$ at $4^{\circ} \mathrm{C}$ with IE8 antibody (diluted either $1 / 100$ for immunofluorescence or $1 / 3000$ for immunoperoxidase in PBS containing $10 \%$ NGiS and $0.1 \%$ Triton $X-100)$. Afterward, sections were incubated sequentially in biotinlabeled anti-mouse IgG (diluted 1/200 in PBS) for $1 \mathrm{hr}$ and rhodamineavidin DCS (diluted 1/100 in PBS, Vector) for $45 \mathrm{~min}$ or, alternatively, with avidin-biotin-peroxidase conjugate (Vector). Peroxidase was developed by immersion in $0.05 \%$ 3,3'-diaminobenzidine (DAB) (Sigma) and $0.01 \%$ hydrogen peroxide in PBS. To reveal nuclear morphology in peroxidase-labeled cells, sections additionally were counterstained by Harris hematoxylin and mounted in DPX. Sections in which 1E8 immunoreactivity was detected by rhodamine fluorescence were processed further to demonstrate DNA fragmentation by means of the TUNEL procedure adapted for a fluorescein end-product. This was accomplished using an in situ cell-death detection kit from Boehringer Mannheim. Double-fluorescent-labeled sections were observed in the confocal microscope viewed after excitation with a $543 \mathrm{~nm}$ Helium/ Neon or a $488 \mathrm{~nm}$ Argon ion laser sources.

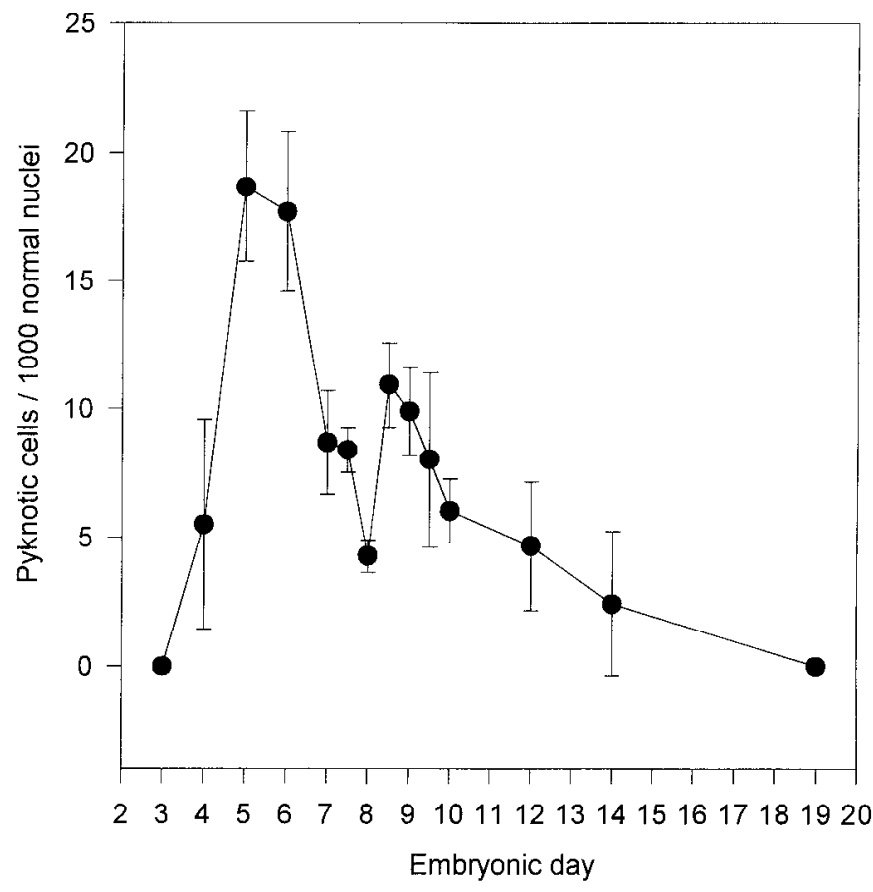

Figure 2. Developmental regulation of normally occurring Schwann cell death in L3 ventral nerve roots from chick embryo. The number of pyknotic Schwann cells was plotted as a function of the developmental age. Each point represents the mean \pm SEM of 3-10 different embryos. 


\section{RESULTS}

\section{Normally occurring Schwann cell death}

The present results demonstrate for the first time in the chick embryo that during normal development, Schwann cells undergo a period of naturally occurring cell death. In the light microscope, dying Schwann cells can be clearly identified in peripheral nerves as scattered, rounded pyknotic cells intermixed with the more numerous fusiform Schwann cells within peripheral nerve profiles. These pyknotic cells belong to the Schwann cell lineage as indicated by positive 1E8 labeling, and they also exhibit positive TUNEL staining (Fig. 1a). The relative amount of naturally occurring Schwann cell death was assessed in L3 ventral nerve roots in serially sectioned Nissl-stained preparations at different stages of development. As shown in Figure 2, pyknotic Schwann cells were absent on E3; the density of dying Schwann cells increases dramatically after E3, showing a biphasic profile with peaks on E5-6 and E8.5, followed by a gradual decrease until E19, when no pyknotic Schwann cells were observed.

\section{NMDA induces excitotoxic motoneuron cell death and Schwann cell apoptosis in ventral nerve roots}

Spinal cords from E7.5 chick embryos were severely altered after treatment in ovo with $1 \mathrm{mg}$ of NMDA. Although initial changes could be observed as early as $30 \mathrm{~min}$ after NMDA application, the pathological reaction reached its peak several hours later. For the purposes of the present investigation, only the changes observed $12 \mathrm{hr}$ after NMDA administration will be described here (Fig. $3 a-d)$. The most affected areas were located in the ventral and intermediate regions of the gray matter, whereas no damage was apparent in dorsal regions of the gray matter or in the white matter (Fig. 3b). In the lateral motor column, large motoneurons showed prominent cytopathological changes consisting of cytoplasmic swelling, vacuolization, loss of the Nissl substance, hyperchromatic nuclei, and some degree of cellular loss that especially affect those neurons located medially within the lateral motor nucleus (Fig. 3d). Acute damage was also observed throughout the intermediate gray matter, in which the most conspicuous alteration consists of severe interstitial edema, cellular depletion, and the accumulation of large numbers of pyknotic cells. Although the central canal appears distended, neuroepithelial cells exhibit normal morphology. In contrast to the severe damage within the spinal cord, dorsal root ganglia (DRG) always appeared normal (Fig. 3c).

In NMDA-treated spinal cord, large numbers of pyknotic cells were also observed within ventral nerve roots, and to a lesser extent, more distally in the peripheral nerves. By contrast, few pyknotic cells were observed in dorsal nerve roots (Figs. $4 a, b, 10)$.
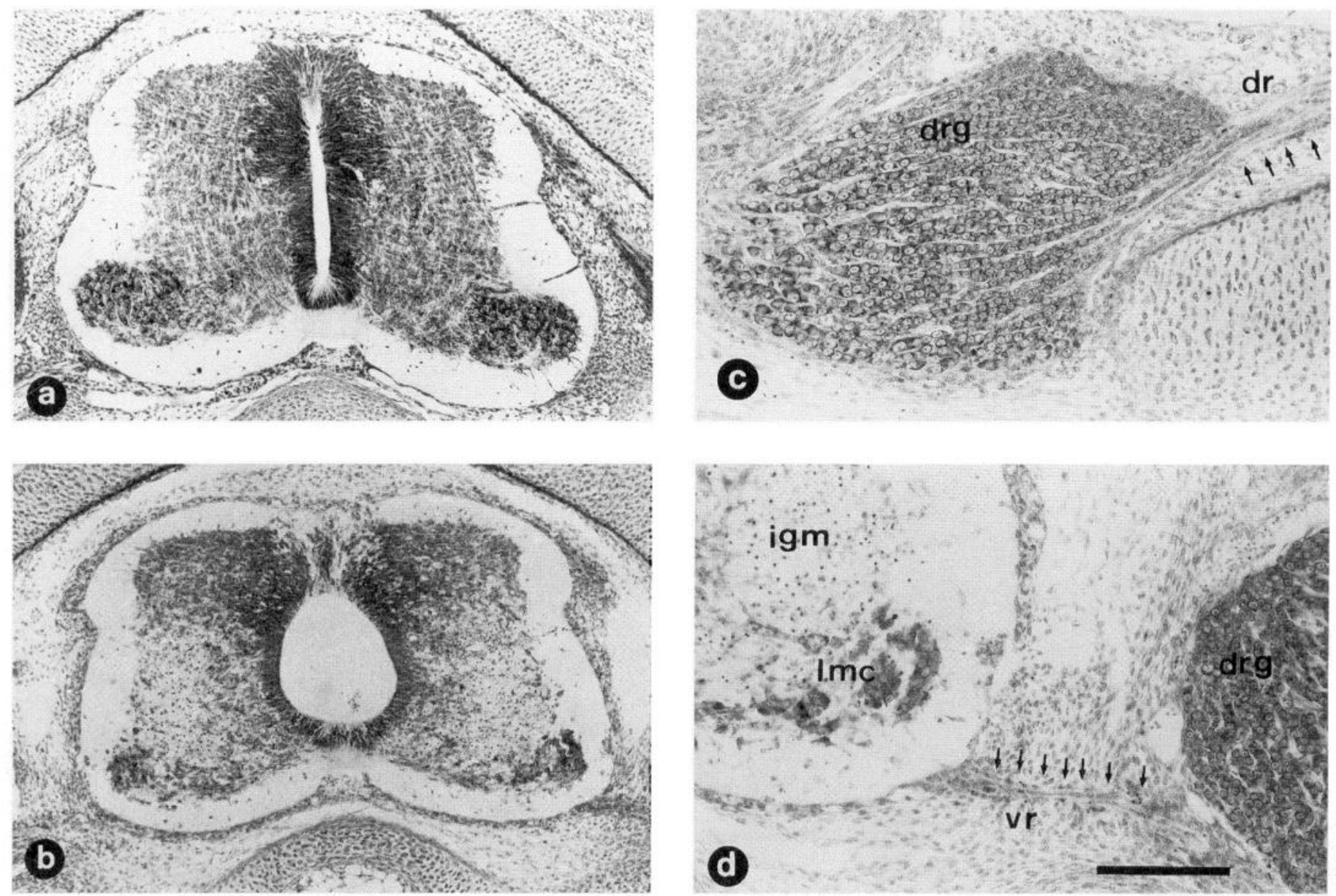

Figure 3. NMDA treatment produces severe damage in the spinal cord but not in DRG. Transverse paraffin sections of lumbar spinal cord from E7.5 chick embryos $12 \mathrm{hr}$ after in ovo treatment with a single injection of either saline solution $(a)$ or $1 \mathrm{mg}$ of NMDA $(b-d)$. Sections were stained with thionin. Note in $b$ and $d$ the severe cellular depletion in the lateral motor column $(\operatorname{lmc})$ that extends through the intermediate gray matter (igm); the central canal appears distended, and many pyknotic cells are present in the ventral nerve root ( $v r$ ) (identified by arrows in $d$ ). No damage is observed in the dorsal region of the gray matter or in dorsal root ganglia ( $d r g)$ or dorsal nerve root ( $d r$ ) (identified by arrows in $c$ ). Scale bar (shown in $d$ ): $a, b, 100 \mu \mathrm{m} ; c, d, 50 \mu \mathrm{m}$. 

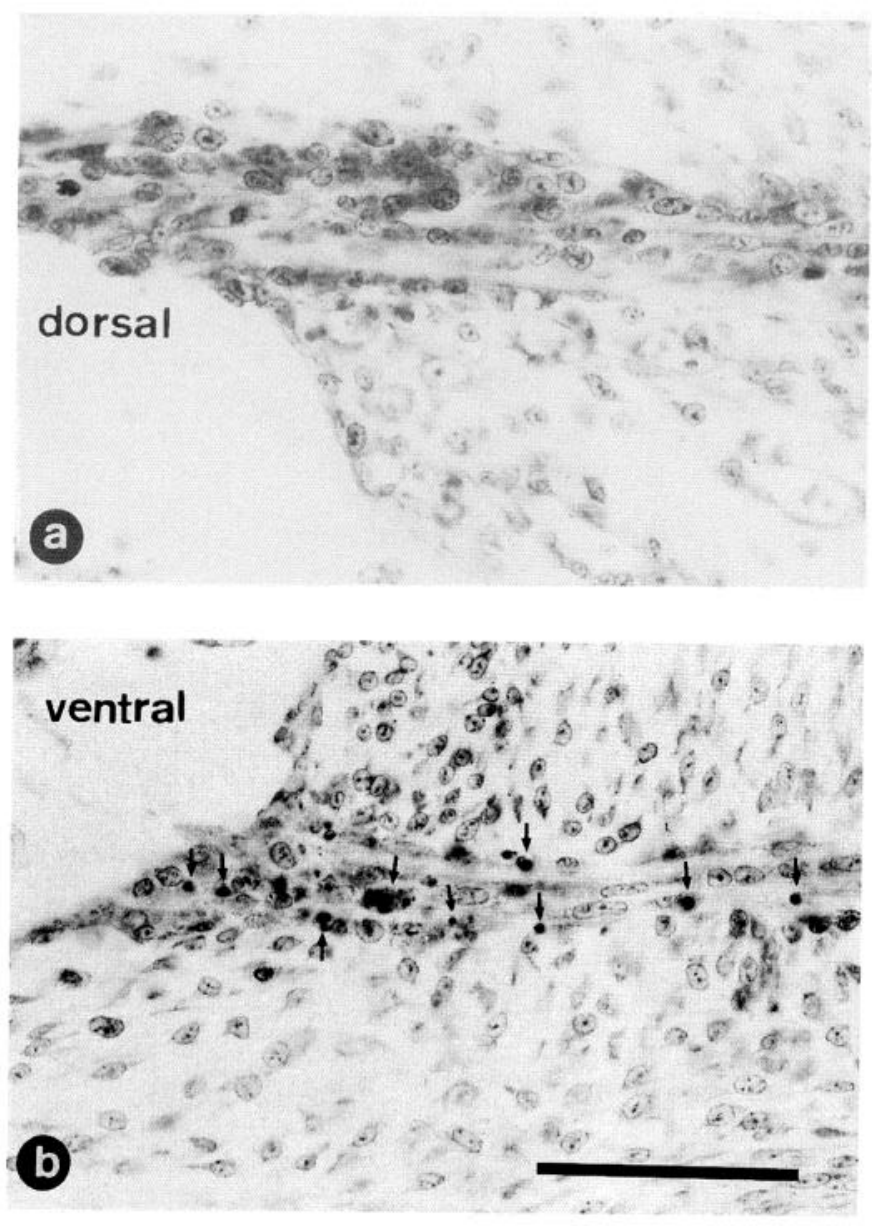

Figure 4. NMDA treatment induces Schwann cell death in ventral but not in dorsal nerve roots. Higher magnification view of a section through L3 dorsal ( $a$ ) or ventral $(b)$ nerve roots from an E7.5 chick embryo $12 \mathrm{hr}$ after treatment with $1 \mathrm{mg}$ of NMDA. Note the large number of pyknotic cells (arrows) exclusively present in the ventral nerve roots; no pyknotic cells are present in the dorsal nerve root. Scale bar (shown in $b$ ): $50 \mu \mathrm{m}$.

Ultrastructurally, motoneurons exhibited conspicuous degenerative changes. The rough endoplasmic reticulum was distended and fragmented into large membrane-bound vesicles that were devoid of attached ribosomes, and mitochondria appeared either swollen or shrunken, with a dark appearance and distended cristae. Nuclear profiles were irregular, and chromatin was clumped into small condensed aggregates. Some cells displayed a dark cytoplasm filled with vacuoles and irregular outlined nuclei with condensed chromatin. Other motoneurons showed a more advanced degree of disruption of cellular morphology displaying rupture of nuclear and plasma membranes and severe organelle alterations (Fig. 5a,b). All of these changes are more characteristic of a necrotic versus an apoptotic form of cell death.

To visualize the morphology of ventral and dorsal axons after NMDA treatment, we applied DiI to fixed specimens. This technique allows one to follow long trajectories of peripheral axons and visualize cell bodies of large ventral horn motoneurons and DRG neurons (Fig. 6a). The most optimal labeling was obtained within 2-3 hr after NMDA treatment (i.e., $150 \mathrm{~min}$ ). A likely explanation for this is that the excessive damage of axons that occurred later (i.e., $12 \mathrm{hr}$ ) after NMDA application probably impairs the ability of DiI to label neurons. DiI-labeled ventral axons from NMDA-treated embryos showed focal swellings and a large number of varicosities (Fig. $6 c$ ) compared with dorsal root axons that showed a normal smooth appearance in continuity with DRG neuron cell bodies (Fig. $6 b$ ). Swellings were seen only rarely in ventral axons from control embryos treated with saline.

Ultrastructural examination of ventral nerve roots after NMDA treatment showed that they are composed of densely packed, small axonal bundles surrounded by immature Schwann cells (Figs. $7 a, 8 a$ ). Most of the axons showed degenerative changes in the form of a dark appearance, fragmentation, accumulation of membranous bodies, and often electrodense varicosities (Fig. $7 b, c)$. Scattered Schwann cells that appeared detached from nerve fascicles displayed ultrastructural features of apoptosis such as extreme chromatin condensation, sometimes in the form of peripheral crescents, and nuclear fragmentation, with an electrodense cytoplasm. Both normal and degenerating axonal profiles were often in close proximity with apoptotic Schwann cells (Fig. $8 b, c)$. These ultrastructural features of degenerating Schwann cells are similar to those described previously by Chu-Wang and Oppenheim (1978).

DNA fragmentation is one of the hallmarks for identifying the apoptotic process (Gavrielli et al., 1992). To determine the extent to which apoptosis is present after degeneration induced by NMDA, samples were processed for in situ detection of DNA fragmentation. TUNEL-positive labeling was observed in cells located in the ventral roots (Fig. 9b), whereas very few cells were labeled in the dorsal roots. Labeled cells were also detected in spinal cord intermediate gray matter, but NMDA-injured motoneurons in the lateral motor column were never labeled. A fluorescent TUNEL procedure was used in combination with the specific avian Schwann cell marker 1E8 antibody to demonstrate further that the dying cells inside nerve roots belonged to the Schwann cell lineage. As can be seen in Figure $1 b, c$, cells containing fragmented DNA showed a positive $1 \mathrm{E} 8$ staining. Moreover, by using an immunoperoxidase procedure for the 1E8 antibody in association with hematoxylin counterstaining, we could demonstrate that the pyknotic cells inside nerve roots, which correspond to those counted in Nissl-stained sections, were indeed 1E8positive Schwann cells (not shown).

In many cell types, the occurrence of apoptosis requires new protein synthesis, and in these cases (which include chick motoneurons), apoptosis is inhibited in the presence of agents that block protein synthesis (Martin et al., 1988; Oppenheim et al., 1990; Ciutat et al., 1995). In vivo administration of CHX before treatment with NMDA did not alter the toxic effects of NMDA on motoneurons, but did inhibit the appearance of apoptotic cells in the ventral nerve roots (Figs. 9c, 10). Moreover, the accumulation of pyknotic cells in the intermediate gray matter was also substantially reduced, and $\mathrm{CHX}$ also blocked the appearance of TUNELpositive cells in ventral roots and intermediate spinal gray.

To test the ability of soluble factors present in embryonic tissues to prevent Schwann cell apoptosis after NMDA treatment, several chick embryo-derived extracts (MEX, BEX, SCEX) were applied before Schwann cell apoptosis was induced by NMDA. Counts of pyknotic profiles failed to demonstrate any significant reduction of Schwann cell apoptosis after these treatments. Administration of MCM also did not prevent NMDA-induced apoptosis of Schwann cells (Fig. 11).

\section{$\beta$-Bgtx induces cell death in sensory and motor neurons, and Schwann cell apoptosis in dorsal and ventral nerve roots}

To demonstrate that Schwann cell apoptosis seen after NMDA administration is unrelated to any direct toxic effect of NMDA, 


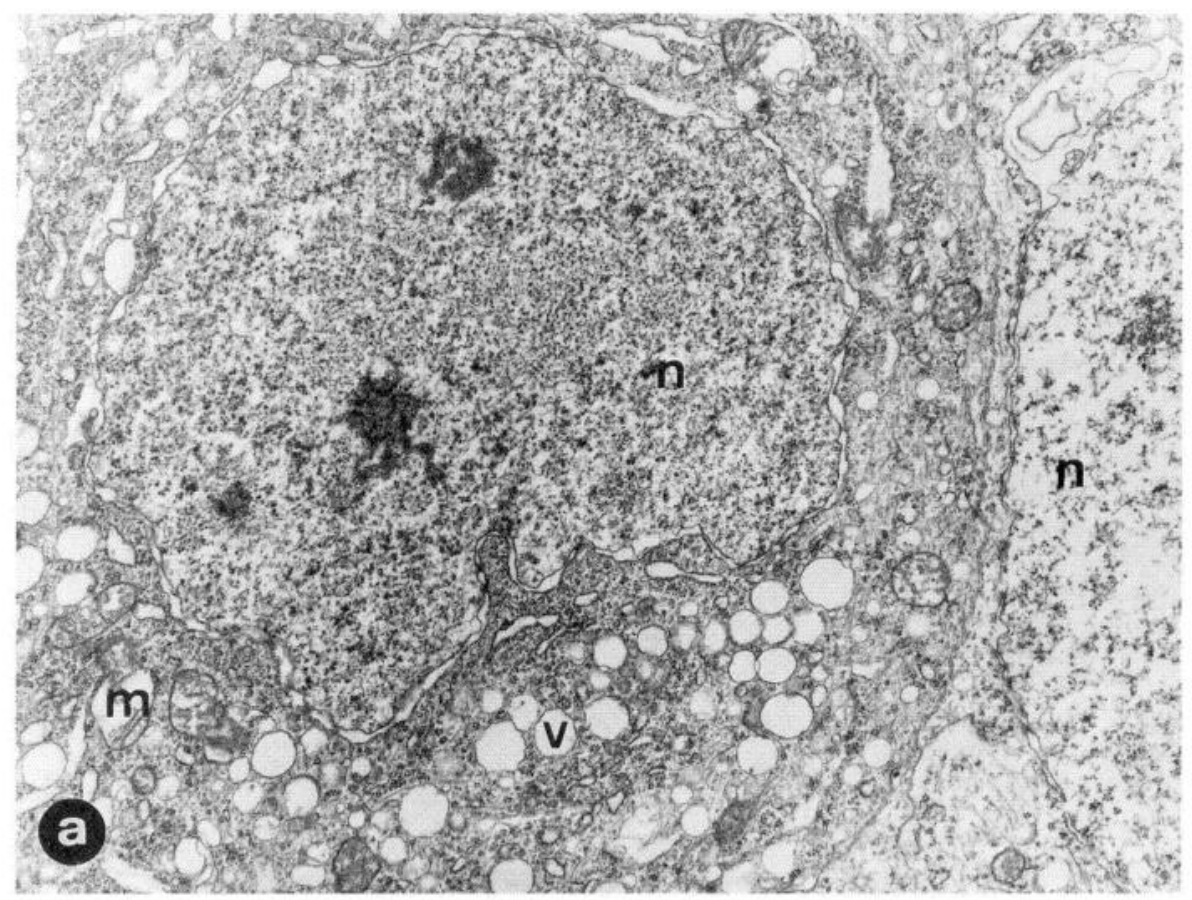

Figure 5. Ultrastructural demonstration of acute motoneuronal damage induced by NMDA. Samples were taken from E7.5 chick embryo $12 \mathrm{hr}$ after treatment with $1 \mathrm{mg}$ of NMDA. $a$, Motoneuron cell body showing accumulation of small membrane-bounded vacuoles $(v)$, dilatation of rough endoplasmic reticulum, swollen mitochondria $(m)$, and nucleus $(n)$ with chromatin aggregated in fine granules. In $b$, a more advanced stage of motoneuronal degeneration showing extreme organelle disruption $(*)$, condensed mitochondria $(m)$, and disruption of plasma membrane (arrows) and nuclear envelope (arrowheads). Scale bar (shown in $b$ ): $a, 5 \mu \mathrm{m} ; b, 7 \mu \mathrm{m}$.

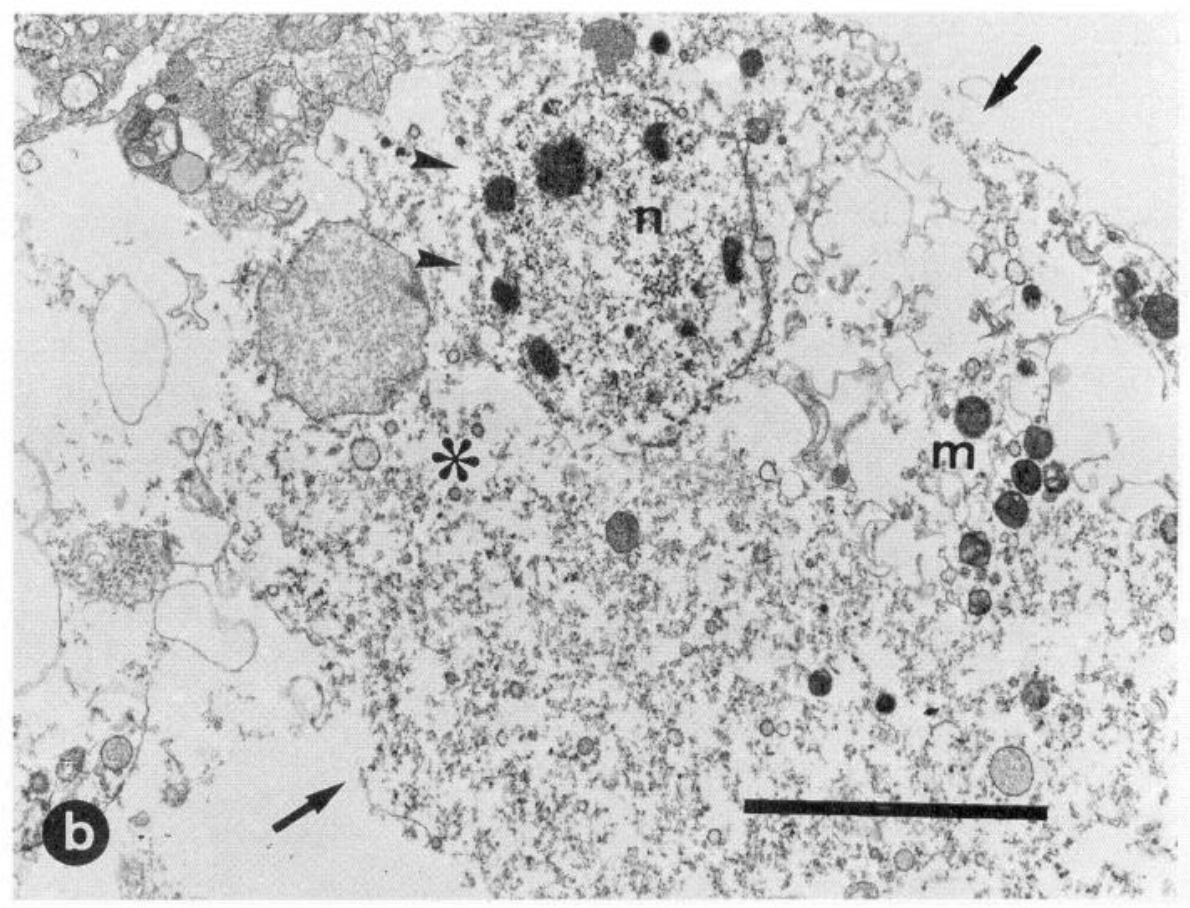

we examined whether other neurotoxic agents that kill neurons by a different mechanism not associated with glutamate receptor overactivation also induce apoptotic Schwann cell death. $\beta$-Bgtx fulfills this condition (Lee and Ho, 1980), and in the chick embryo intramuscular administration of this neurotoxin, it destroys both motoneurons and DRG neurons (Pittman et al., 1978). We injected $100 \mathrm{ng}$ of $\beta$-Bgtx in the ventral muscular masses of the leg on E7. Twelve hours later, a massive accumulation of dying cells was observed inside the DRG (Fig. $12 a$ ). The most affected cells were the ventrolateral sensory neurons, which also display a TUNEL-positive reaction (not shown). In the LMC, motoneurons also were severely affected by the toxin; however, the cytological features of dying motoneurons seem to reflect a necrotic form of cell death, because cytoplasmic degeneration and the loss of basophilia associated with fine punctate pyknotic nuclei predominates (Fig. $12 b)$, and the dying motoneurons did not show positive TUNEL staining.

The number of pyknotic Schwann cells was increased substantially in both ventral and dorsal nerve roots as a consequence of $\beta$-Bgtx treatment (Fig. 10). Therefore, neuronal death induces apoptosis in Schwann cells after destruction of peripheral axons by two distinct neurotoxic mechanisms (NMDA and $\beta$-Bgtx). 

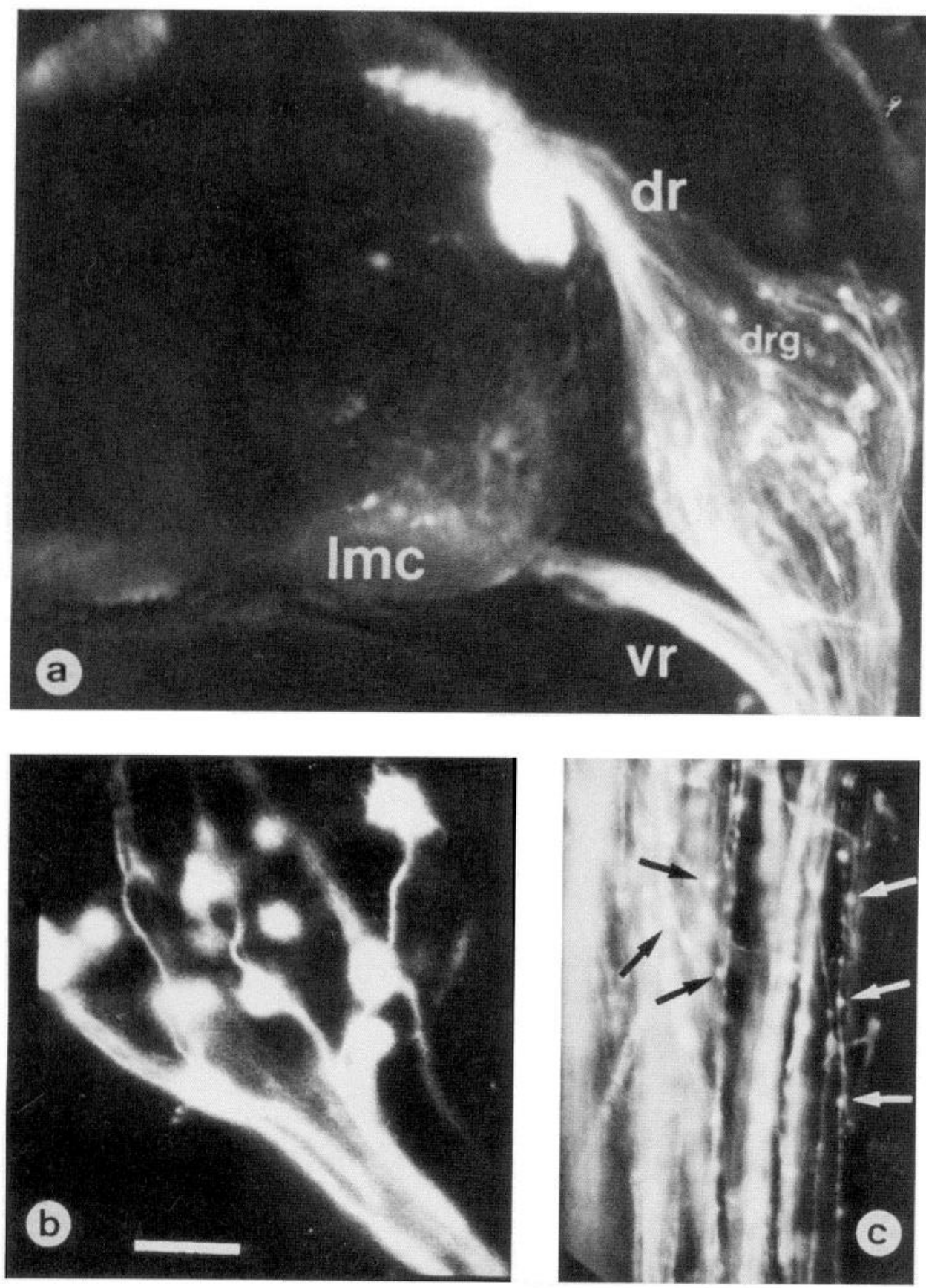

Figure 6. Neuronal DiI tracing in an NMDA-treated embryo. Confocal laserscanning micrographs of a transverse section from E7.5 chick embryo spinal cord $150 \mathrm{~min}$ after treatment with $1 \mathrm{mg}$ of NMDA. $a$, Embryo was processed for visualization of ventral $(v r)$ and dorsal $(d r)$ nerve fibers by means of DiI labeling; some ganglionic cells in dorsal root ganglion ( $\mathrm{drg}$ ) and motoneuronal cell bodies in lateral motor column $(l m c)$ are also labeled. $b, c$, High-magnification micrographs of axonal profiles present in dorsal $(b)$ or ventral $(c)$ nerve roots showing the presence of large numbers of varicosities only in the ventral axons (arrows). Scale bar (shown in b): $a, 125 \mu \mathrm{m} ; b, 25 \mu \mathrm{m} ; c, 50 \mu \mathrm{m}$.

\section{DISCUSSION}

\section{Normally occurring Schwann cell death}

The naturally occurring programmed cell death of chick embryo Schwann cells was first described by Chu-Wang and Oppenheim (1978). They observed apoptotic Schwann cells in the lumbar ventral roots during the same period as naturally occurring motoneuron death (E6-12) as well as an apparent increased death of Schwann cells after limb-bud removal (Oppenheim et al., 1978), and suggested that Schwann cell death may be a response to the loss or absence of axonal-derived survival signals. In the present study, we have confirmed the existence of a normal loss of Schwann cells by apoptosis and have shown that Schwann cell death is increased selectively after neuronal death and loss of axons induced by neurotoxins. A more careful comparison between the developmental profile of normal Schwann cell and motoneuron death in the chick embryo lumbar spinal cord shows that Schwann cell apoptosis exhibits an initial peak 1 or $2 \mathrm{~d}$ (E5-6.5) before the number of pyknotic cells in LMC reaches its maximum (E8; Oppenheim et al., 1990). A possible explanation for this apparent dissociation may be related to some of the initial events occurring in developing nerve roots, including early interactions of growing axons with primitive Schwann cell clusters. These initial steps have been well described in mammalian embryos (Gamble, 1976). From these data, it can be expected that at least two overlapping waves of physiological Schwann cell death should exist. Initially, growing axons are grouped in fascicles containing undifferentiated Schwann cells. Because axons probably differ in their opportunity to interact with Schwann cells, some Schwann cells receive little if any axonal-derived signals necessary for their survival. This would initiate the first wave of Schwann cell 

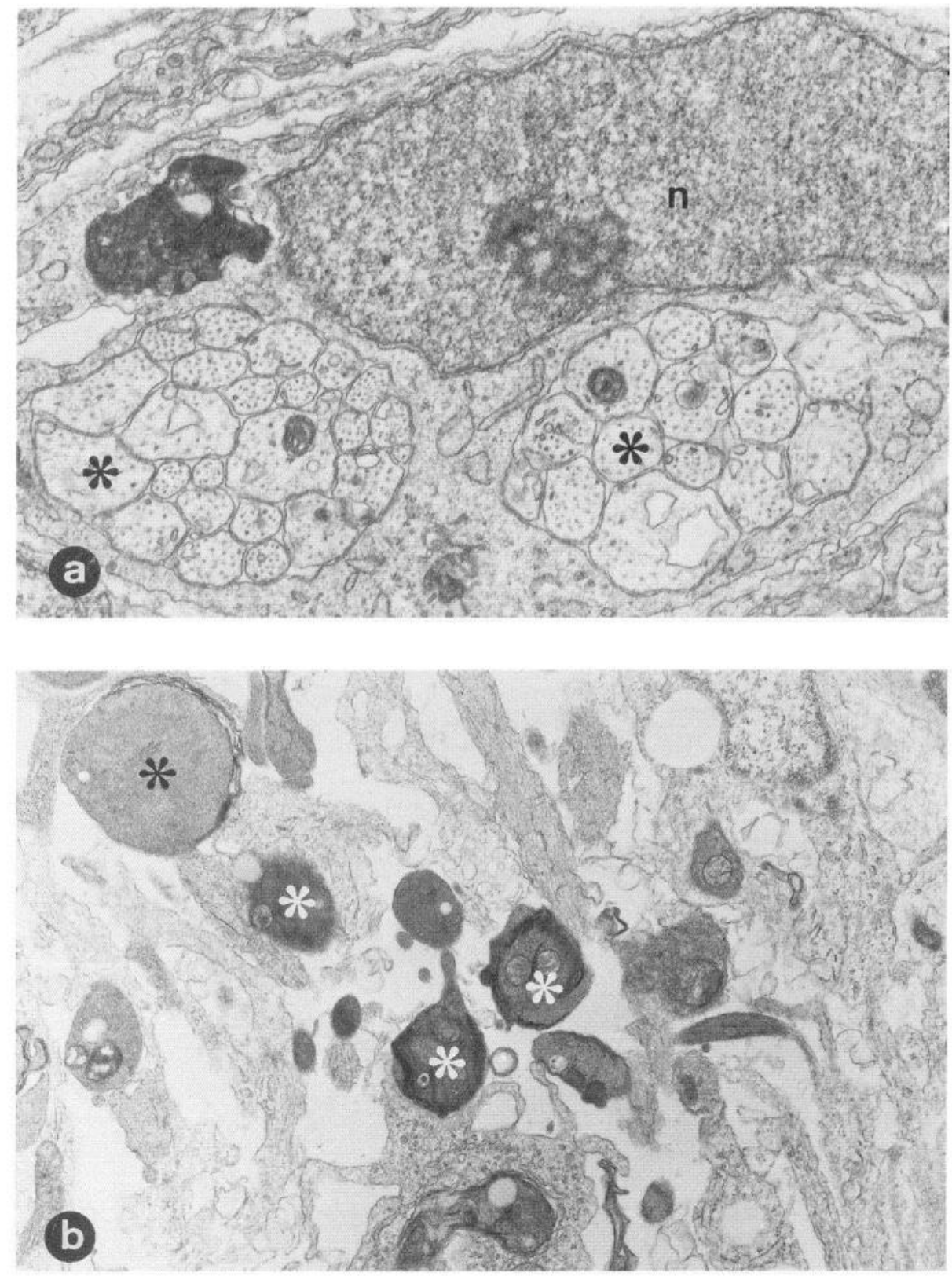

Figure 7. Ultrastructural morphology of ventral nerve root axons from normal and NMDAtreated embryos. Electron micrographs were taken from E7.5 chick embryos $12 \mathrm{hr}$ after treatment with either saline $(a)$ or $1 \mathrm{mg}$ of NMDA $(b$, $c)$. Compare the normal morphology of axons (*) in $a$ surrounded by an immature Schwann cell with the dark appearance of degenerated axons in $b$; some degenerated axons (arrows) showing varicosities with accumulation of degenerated organelles can be seen $(c) . n$, Schwann cell nucleus. Scale bar (shown in $c$ ): $a, 1.5 \mu \mathrm{m} ; b, 2.90$ $\mu \mathrm{m} ; c, 1.45 \mu \mathrm{m}$.

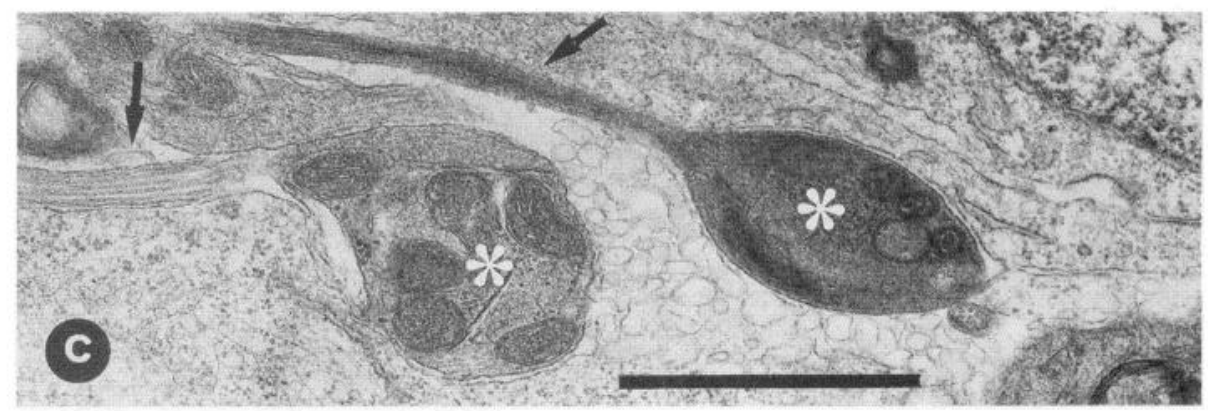

apoptosis, which is unrelated to motoneuron death. Later, when motoneurons begin to undergo naturally occurring cell death, some motor axons that had interacted previously with Schwann cells degenerate and induce a second wave of Schwann cell apoptosis that would account for the second peak (on E8.5). Although this scheme fits well with the developmental profile of programmed
Schwann cell death described here, additional detailed studies of Schwann cell death and Schwann cell-axon interactions during these stages are needed to confirm this hypothesis. Normal death of developing Schwann cells also was reported recently to occur at newborn rat neuromuscular endplates, and axotomy increases this cell loss (Trachtenberg and Thompson, 1996). 

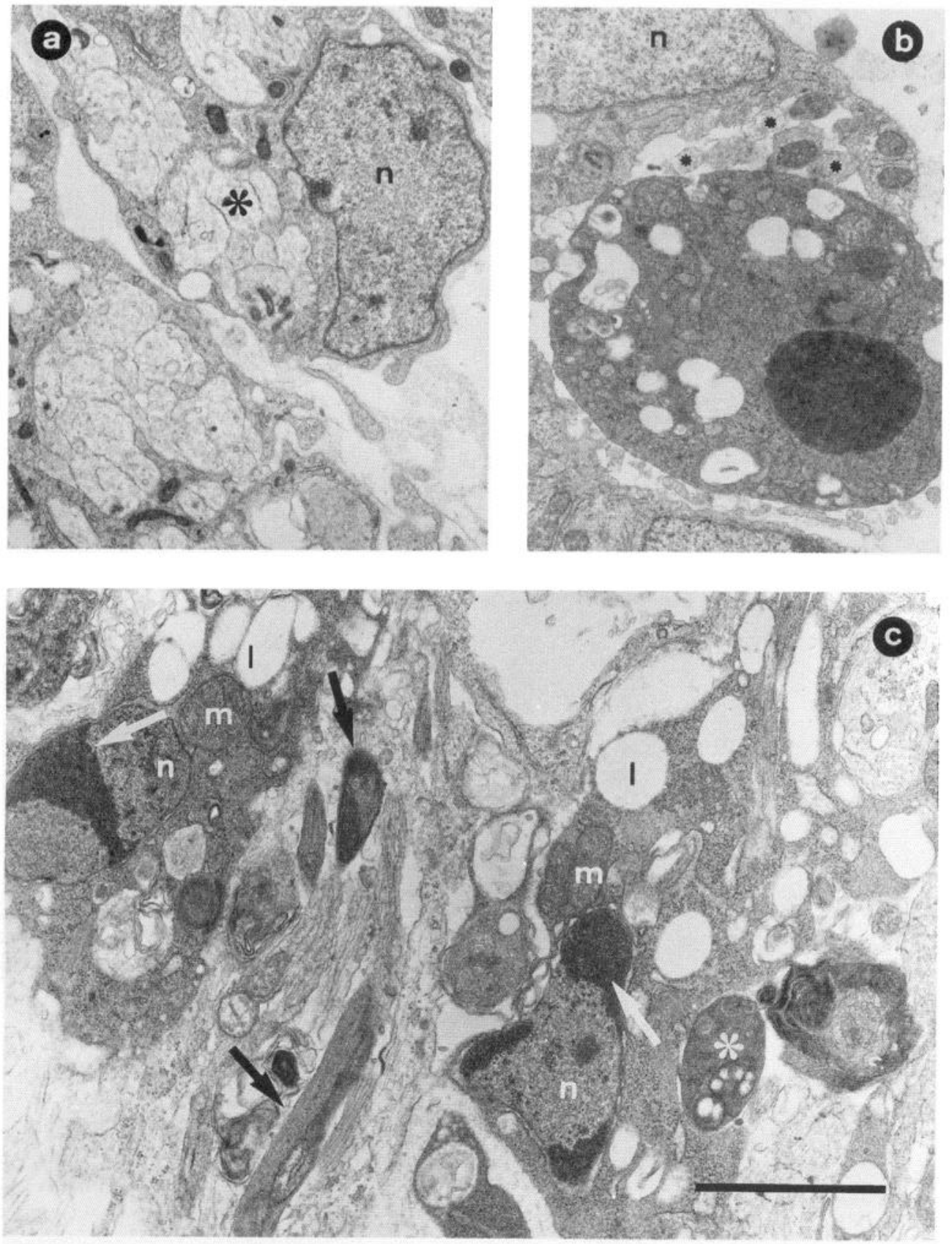

Figure 8. Ultrastructural morphology of ventral nerve root Schwann cells from normal and NMDA-treated embryos. Electron micrographs were taken from E7.5 chick embryos $12 \mathrm{hr}$ after treatment with either saline $(a)$ or $1 \mathrm{mg}$ of NMDA $(b, c)$. In $a$, an immature Schwann cell $(n)$ is seen surrounding densely packed fascicles of axons (*). $b$, One Schwann cell with typical apoptotic morphology is seen near clustered nerve fibers $(*)$ and adjacent to a normal Schwann cell $(n)$. In $c$, two Schwann cells with initial apoptotic changes are seen. Note the marginal clustering of condensed chromatin (white arrows) in the Schwann cell nucleus $(n)$ and the dark appearance of the cytoplasm containing lipid droplets $(l)$ and mitochondria $(m)$. Degenerating axons are seen adjacent (black arrows) or in close contact (*) with apoptotic Schwann cells. Scale bar (shown in $c$ ): $a, 2 \mu \mathrm{m} ; b, 2.6 \mu \mathrm{m}$; $c, 1.80 \mu \mathrm{m}$.

\section{Neurotoxin-induced Schwann cell apoptosis}

The experiments reported here also demonstrate that spinal cord motoneurons are selectively damaged by administration in ovo of NMDA and that Schwann cells surrounding motor axons subsequently die by apoptosis. The histological pattern of motoneuron injury is similar to excitotoxic lesions that have been described in other neuronal populations after treatment with glutamate receptor agonists (Herndon et al., 1980; Siman and Card, 1988). This type of injury seems to result from an excessive calcium influx elicited by glutamate receptor activation (Choi, 1987, 1992; Rajdev and Reynolds, 1994). Moreover, our observations on spinal cord degeneration induced by NMDA in E7.5 chick embryos are comparable to those described previously by Stewart et al. (1991) in E11 chick embryos exposed to several different excitotoxins. Acute motoneuron degeneration and death induced by NMDA administration reflects a necrotic rather than an apoptotic type of cell death. NMDA treatment induces cellular swelling, intracytoplasmic vacuolization, and eventual disruption of the plasma membrane rather than cellular shrinkage, chromatin condensation, nuclear fragmentation, and other structural changes that characterize apoptotic cell death (Kerr et al., 1995). In addition, motoneuron death induced by NMDA does not exhibit DNA fragmentation, and CHX does not block NMDA-induced motoneuron death. After NMDA treatment, however, other spinal cells exhibit cytopathological changes that are typical of apoptosis, including positive DNA fragmentation and inhibition by CHX. These include nerve cells located in the intermediate gray matter and Schwann cells in ventral nerve roots. Schwann cell apoptosis induced by NMDA treatment very likely represents a secondary response, because it was strictly confined to ventral roots, which contain axons of injured motoneurons. 

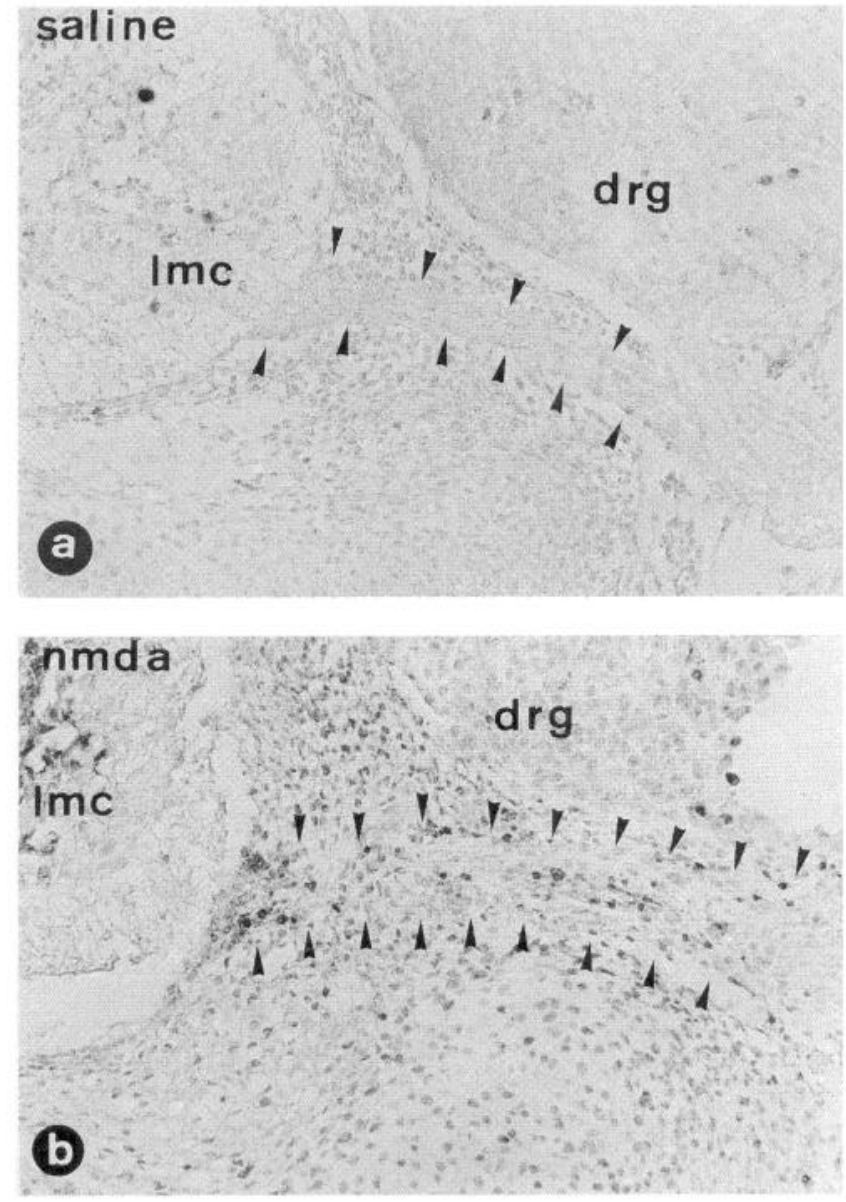

\section{$\mathrm{nmda}+\mathrm{chx}$}

Imc
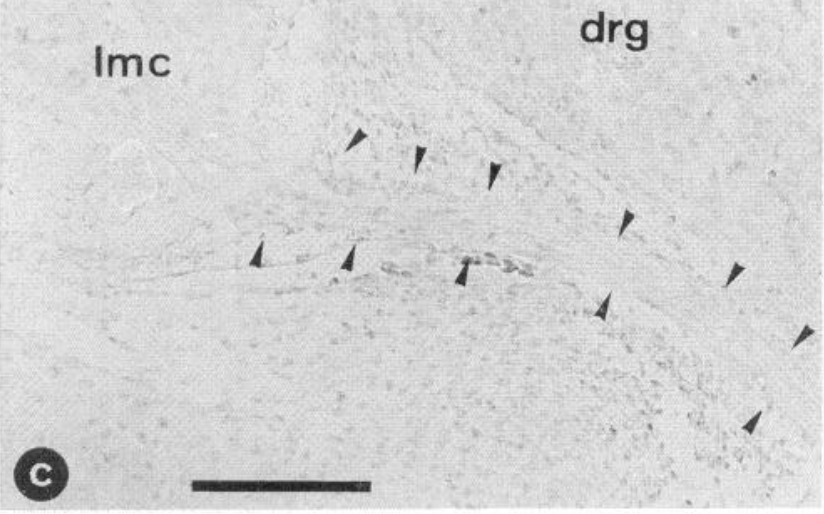

Figure 9. In situ detection of DNA fragmentation. Transverse paraffin sections of lumbar spinal cord from E7.5 chick embryos treated in ovo with saline solution (saline) (a), $1 \mathrm{mg}$ of NMDA (nmda) $(b)$, or both CHX (2 $\mu \mathrm{g}$ every $4 \mathrm{hr})$ and NMDA $(1 \mathrm{mg})(n m d a+c h x)(c)$. Embryos were killed $12 \mathrm{hr}$ after the single dose of either saline or NMDA. Arrowheads delimitate the ventral nerve roots. Note the absence of labeled cells in the embryos treated with saline and both NMDA and CHX. Normal nuclei are lightly labeled because of the methyl green counterstain. $\operatorname{lmc}$, Lateral motor column; $d r g$, dorsal root ganglion. Scale bar, $100 \mu \mathrm{m}$.

Schwann cells in dorsal roots, which surround nerve fibers arising from uninjured DRG neurons, did not undergo apoptosis after NMDA treatment.

The results obtained after $\beta$-Bgtx treatment strengthen this argument, because the anatomical distribution of apoptotic

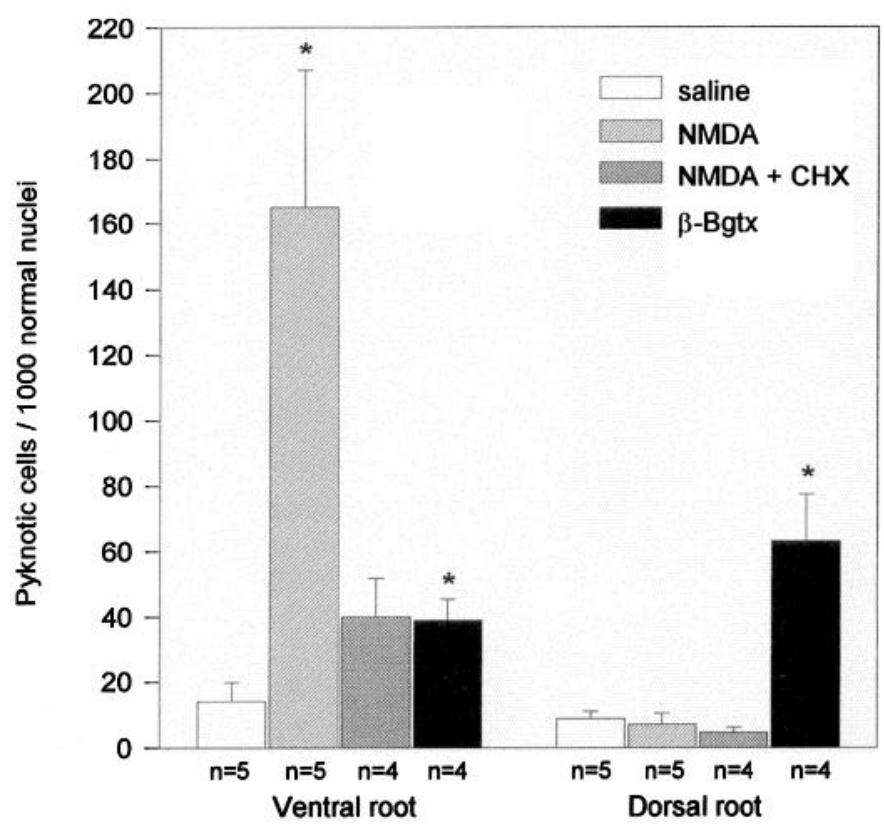

Figure 10. Increased Schwann cell death after treatment with neurotoxins. Number (mean \pm SEM) of pyknotic cells in ventral and dorsal nerve roots from E7.5 chick embryos treated with saline solution, $1 \mathrm{mg}$ of NMDA, $1 \mathrm{mg}$ of NMDA and CHX ( $2 \mu \mathrm{g}$ every $4 \mathrm{hr})$, and $100 \mathrm{ng}$ of $\beta$-Bgtx. Counts were made in each condition $12 \mathrm{hr}$ after the single injection of either saline, NMDA, or $\beta$-Bgtx. $n$, Sample size. ${ }^{*} p \leq 0.05$ versus saline, Student's $t$ test.

Schwann cells seen after the administration of this neurotoxin exactly matches the localization of damaged axons emerging from dying neurons. $\beta$-Bgtx is a neurotoxin isolated from the crude venom of Bungarus multicinctus, which has severe and complex presynaptic actions presumably mediated by its capacity to bind a presynaptic membrane protein and to alter potassium channels and also by its phospholipase $\mathrm{A}_{2}$ activity (Lee and Ho, 1980; Esquerda et al., 1982; Rowan and Harvey, 1988). In the chick embryo peripheral nervous system, the neurons damaged by this toxin were the same as those described by Pittman et al. (1978); i.e., both DRG neurons and LMC motoneurons were affected severely and acutely. Although the exact mechanism by which neurons are killed by $\beta$-Bgtx is still unknown, it is likely that cell bodies degenerate or are induced to undergo programmed cell death in response to an anterograde peripheral nerve degeneration starting at nerve endings, which are a major target of $\beta$-Bgtx action. Acute toxin-induced nerve-terminal degeneration may drastically impair the uptake of target-derived neurotrophic factors that are essential for keeping developing neurons alive. This is consistent with the apoptotic morphology that we have observed in the DRG neurons, but not with the cytology of dying motoneurons in toxin-treated embryos. Perhaps because $\beta$-Bgtx has specific actions at cholinergic nerve terminals, a different mechanism may be responsible for motoneuron death by this neurotoxin. In any case, the main point in the context of the present work is that immature Schwann cells undergo apoptosis when the neurons with which they normally interact are lost after degeneration induced by either NMDA or $\beta$-Bgtx.

The present in vivo observations are consistent with previous suggestions that Schwann cell differentiation and survival are regulated by axonal-derived signals (Chu-Wang and Oppenheim, 1978; Varon and Bunge, 1978; Jessen et al., 1987; Jessen and 


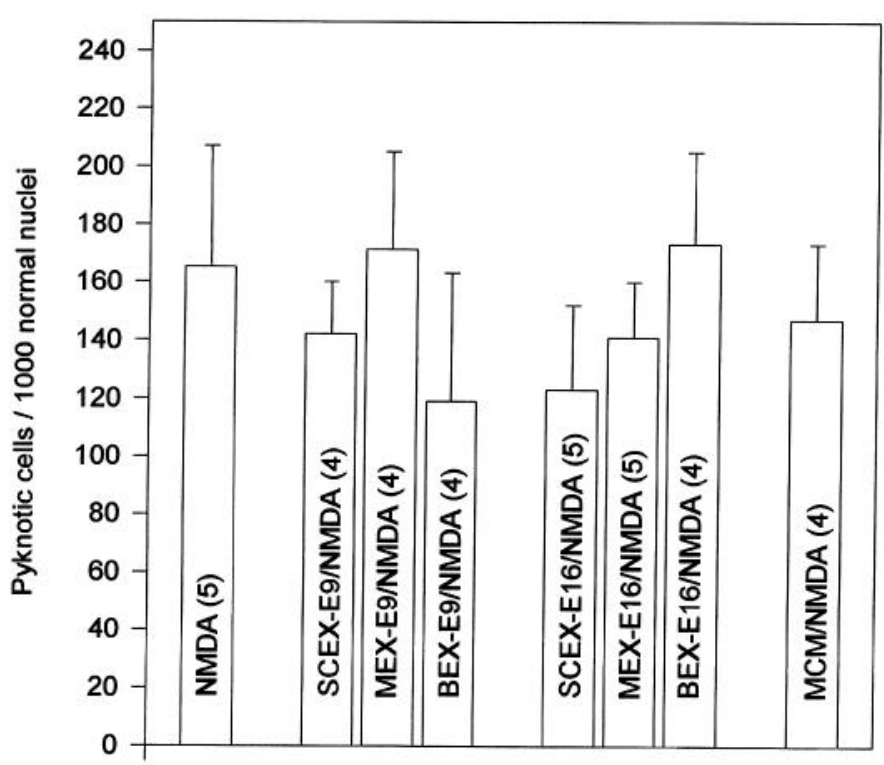

Figure 11. Treatment with embryonic extracts or motoneuron conditioned media does not rescue Schwann cell death after NMDA treatment. Number (mean \pm SEM) of pyknotic Schwann cells in ventral nerve roots on E7.5 NMDA-injected embryos after treatment with saline, spinal cord extract $(S C E X, 150 \mu \mathrm{g})$, muscle extract $(M E X, 150 \mu \mathrm{g})$, brain extract $(B E X, 150 \mu \mathrm{g})$, and motoneuron conditioned medium (MCM, $250 \mu \mathrm{g})$. Tissue extracts were obtained from either E9 or E16 chick embryos; MCM was obtained from $6 \mathrm{~d}$ primary cultures of motoneurons purified from E5.5 chick embryos. For details, see Materials and Methods. Numbers in parentheses indicate sample size.

Mirsky, 1992). Schwann cell precursors undergo apoptosis when cultured in the absence of putative survival factors that are present in neuron conditioned media (Jessen at al., 1994). The so-called Schwann cell precursor is an early cell in the Schwann cell lineage present in E14 rat nerves. It is likely that most of the E7.5 chick embryo Schwann cells are homologous to E14 rat Schwann cell precursors because (1) both are susceptible to apoptosis after withdrawal of neuronal-derived influences and (2) the stage of morphological differentiation of peripheral nerves in E7.5 chick embryos is comparable to that seen in E14 rat embryos. For example, in both species at these ages, myelin is not yet formed, and axons are in tightly packed bundles surrounded by Schwann cell processes (see Fig. 6 for chick embryo and compare with Jessen et al., 1994). Because Schwann cell precursors may be rescued from death in vitro by neuron conditioned media or growth factors (Dong et al., 1995; Gavrilovic et al., 1995), we have tested the ability of motoneuron conditioned medium or chick embryo tissue extracts to inhibit Schwann cell apoptosis in our NMDA paradigm. The negative results obtained here do not exclude the possibility that growth factors released from or contained on the surface of axons could act in vivo to regulate Schwann cell survival, because they may not be present in sufficient amounts in the extracts used in our study. Another possibility is that growth factor action may require direct cell-to-cell contact. For instance, axonal contact seems to modulate oligodendrocyte survival in transected rat optic nerve during development (David et al., 1984; also see Raff et al., 1993), and cell contacts are also necessary for preventing apoptotic cell death in Drosophila glial cells (Sonnenfeld and Jacobs, 1995).

Of the various growth factors that have been tested in vitro, only IGF, FGF, and NDF promote the survival of embryonic mammalian
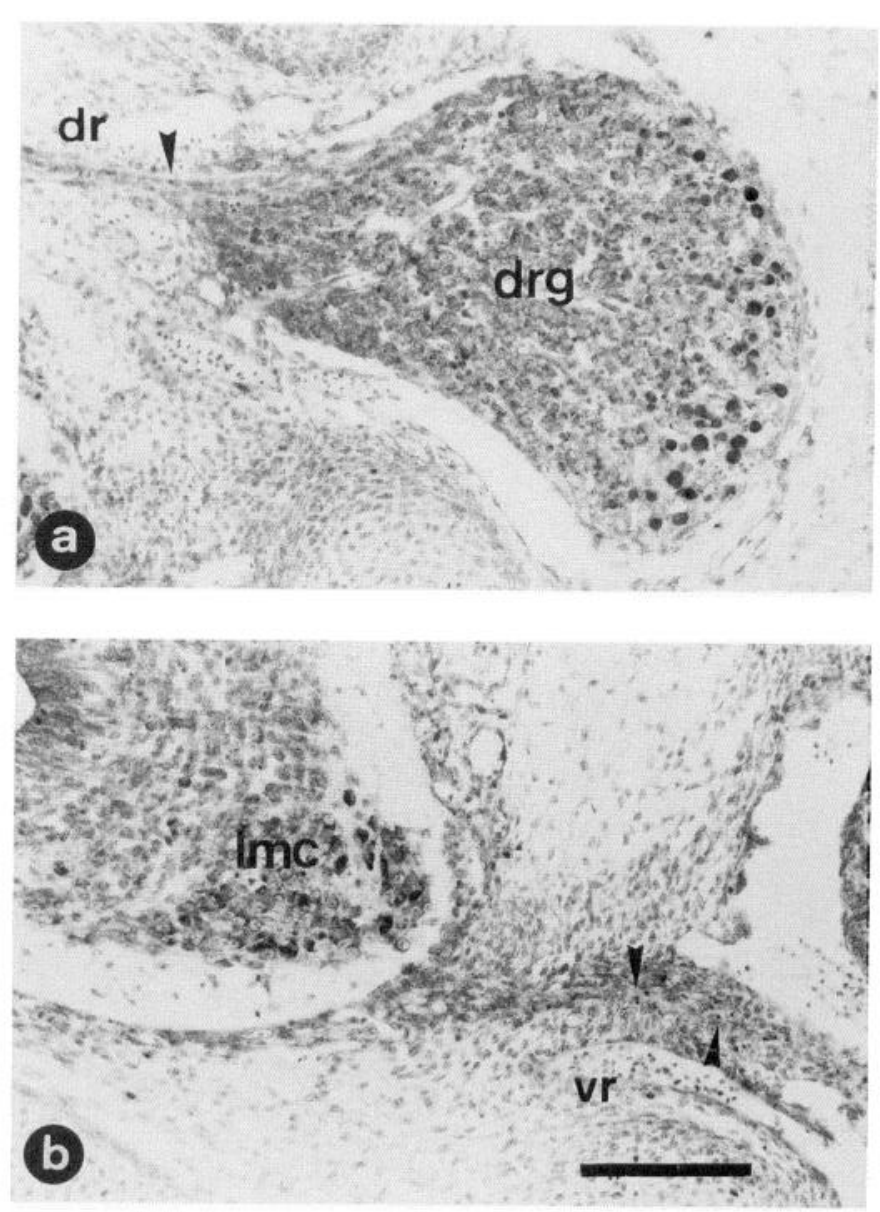

Figure 12. Injection of $\beta$-Bgtx induces cell death in both dorsal root ganglion and lateral motor column neurons. $a$, Transverse paraffin section stained with thionin showing the massive death of dorsal root ganglion $(\mathrm{drg})$ ventrolateral neurons $12 \mathrm{hr}$ after a single intramuscular injection of $\beta$-Bgtx (100 ng) on E7 chick embryos. In $b$, a section of spinal cord from the same embryo in which the extensive spaces observed within the lateral motor column $(\operatorname{lmc})$ were induced by the acute motoneuron loss, whereas some degenerating motoneurons can be observed as dark-stained profiles. Although the photos were taken at low magnification, some pyknotic Schwann cells can be identified in both dorsal $(a, d r)$ and ventral $(b, v r)$ nerve roots (arrowheads). Scale bar, $100 \mu \mathrm{m}$.

Schwann cells (Dong et al., 1995; Gavrilovic et al., 1995). GGF, another member of the neuregulin gene family, can rescue neonatal rat Schwann cells at the neuromuscular junction from apoptotic cell death in vivo after axotomy (Trachtenberg and Thompson, 1996), and a targeted mutation of the neuregulin gene in mice is reported to reduce the number of Schwann cells in the peripheral nerves of E10.5 embryos (Meyer and Birchmeier, 1995). GGF is expressed in developing mouse embryo sensory neurons (DRG) and motoneurons as early as E11.5 (Marchionni et al., 1993), a stage of development comparable to an E3-4 chick embryo, which is when we have observed the onset of programmed cell death of Schwann cells in the present study. Studies are presently underway to determine whether neuregulins or other growth factors can rescue embryonic chicken Schwann cells from normal and neurotoxin-induced programmed cell death in vivo.

In conclusion, by using neurotoxins, we have defined a new model for studying Schwann cell apoptosis in vivo that may be useful in future studies for identifying and characterizing the normal signals that regulate survival and differentiation of peripheral glial cells. 


\section{REFERENCES}

Aguayo AJ, Terry LC, Bray GM (1973) Spontaneous loss of axons in sympathetic unmyelinated nerve fibres of the rat during development. Brain Res 54:360-364.

Bhattacharyya A, Frank E, Ratner N, Brackenbury R (1991) $P_{0}$ is an early marker of the Schwann cell lineage in chickens. Ncuron 7:831-844.

Barde Y-A (1984) Trophic factors and neuronal survival. Neuron 2:1525-1534.

Barde Y-A (1994) Neurotrophic factors: an evolutionary perspective. J Neurobiol 25:1329-1333.

Barres BA, Raff MC (1994) Control of oligodendrocyte number in the developing rat optic nerve. Neuron 12:935-942.

Barres BA, Hart IK, Coles HSR, Burne JF, Voyvodic JT, Richardson WD, Raff MC (1992a) Cell death and control of cell survival in the oligodendrocyte lincage. Cell 70:31-46.

Barres BA, Hart IK, Coles HSR, Burne JF, Voyvodic JT, Richardson WD, Raff MC (1992b) Cell death in the oligodendrocyte lineage. J Neurobiol 23:1221-1230.

Berthold CH (1973) Local demyelination in developing feline nerve fibres. Neurobiology 3:339-352.

Bray GM, Rasminsky M, Aguayo AJ (1981) Interactions between axons and their sheath cells. Annu Rev Neurosci 4:127-162.

Choi DW (1987) Ionic dependence of glutamate neurotoxicity. J Neurosci 7:369-379.

Choi DW (1992) Excitotoxic cell death. J Neurobiol 23:1261-1276.

Chu-Wang IW, Oppenheim RW (1978) Cell death of motoneurons in the chick embryo spinal cord. II. A quantitative and qualitative analysis of degeneration in the ventral root, including evidence for axon outgrowth and limb innervation prior to cell death. J Comp Neurol 177:59-86.

Ciutat D, Esquerda JE, Calderó J (1995) Evidence for calcium regulation of spinal cord motoneuron death in the chick embryo in vivo. Dev Brain Res 86:167-179.

Clarke PGH, Oppenheim RW (1995) Neuron death in vertebrate development: in vivo methods. In: Methods in cell biology: cell death, vol 46 (Schwartz LM, Osborne BA, eds), pp 277-321. New York: Academic.

Comella JX, Sanz-Rodriguez C, Aldea M, Esquerda JE (1994) Skeletal muscle-derived trophic factors prevent motoneurons from entering an active cell death program in vitro. J Neurosci 14:2674-2686.

Cowan WM, Fawcett JW, O'Leary DDM, Stanfield BB (1984) Regressive events in ncurogencsis. Science 225:1258-1265.

David S, Miller RH, Patel R, Raff MC (1984) Effects of neonatal transection on glial cell development in the rat optic nerve: evidence that oligodendrocyte-type 2 astrocyte cell lineage depends on axons for its survival. J Neurocytol 13:961-974.

Davis AM (1994) The role of neurotrophins in the developing nervous system. J Neurobiol 25:1334-1348.

Dong Z, Brennan A, Liu N, Yarden Y, Lefkowitz G, Mirsky R, Jessen KR (1995) Neu differentiation factor is a neuron-glia signal and regulates survival, proliferation and maturation of rat Schwann cell precursors. Neuron 15:585-596.

Esquerda JE, Solsona C, Marsal J (1982) Binding of $\beta$-bungarotoxin to Torpedo electric organ synaptosomes. A high resolution autoradiographic study. Neuroscience 7:751-758.

Gamble HJ (1976) Spinal and cranial nerve roots. In: The peripheral nerve (I andon DN, ed), pp 330-354. Iondon: Chapman and Hall.

Gavrielli Y, Sherman Y, Ben-Sasson SA (1992) Identification of programmed cell death in situ via specific labeling of nuclear DNA fragmentation. J Cell Biol 119:493 501.

Gavrilovic H, Brennan A, Mirsky R, Jessen KR (1995) Fibroblast growth factors and insulin growth factors combine to promote survival of rat Schwann cell precursors without induction of DNA synthesis. Eur $\mathbf{J}$ Neurosci 7:77-85.

Hamburger V, Hamilton HL (1951) A series of normal stages in the development of the chick embryo. J Morphol 88:49-92.

Herndon RM, Coyle JT, Addicks E (1980) Ultrastructural analysis of kainic acid lesion to cerebellar cortex. Neuroscience 5:1015-1026.

Jacobson M (1991) Neuroglial ontogeny. In: Developmental neurobiology, pp 95-142. New York: Plenum.

Jessen KR, Mirsky R (1992) Schwann cells: early lineage regulation of proliferation and control of myelin formation. Curr Opin Neurobiol 2:575-581.

Jessen KR, Brennant $\Lambda$, Morgan L, Mirsky R, Kent A, Hasimoto Y, Cavrilovic J (1994) The Schwann cell precursor and its fate: a study of cell death and differentiation during gliogenesis in rat embryonic nerves. Neuron 12:509-527.

Jessen KR, Mirsky R, Morgan L (1987) Axonal signals regulate the differentiation of non-myelin-forming Schwann cells: an immunohistochemical study of galactocerebroside in transected and regenerating nerves. J Neurosci 7:3362-3369.

Kerr JFR, Gobé GC, Winterford CM, Harmon BV (1995) Anatomical methods in cell death. In: Methods in cell biology, vol 46, Cell death (Schwartz LM, Osborne BA, eds), pp 1-27. San Diego: Academic.

Krueger BK, Burne JF, Raff MC (1995) Evidence for large-scale astrocyte death in the developing cerebellum. J Neurosci 15:3366-3374.

Lce CY, Ilo CL (1980) Pharmacology of presynaptic neurotoxin from snake venoms. In: Natural toxins (Eaker D, Wadstrom T, eds), pp 539-547. Oxford: Pergamon.

Lindsay RM, Wiegand SJ, Altar CA, DiStefano PS (1994) Neurotrophic factors: from molecule to man. Trends Neurosci 17:182-190.

Lowry OH, Rosebrough NJ, Farr AL, Randall RJ (1951) Protein measurement with folin phenol reagent. J Biol Chem 193:265-275.

Marchionni MA, Goodearl ADJ, Chen MS, Bermingham-McDonogh O, Kirk C, Hendricks M, Danehy F, Misumi D, Sudhalter I, Kobayashi K, Wrobelwski D, Lynch C, Baldassare M, Hiles I, Davis JB, Hsuan JJ, Totty NF, Otsu M, McBurney RN, Waterfield MD, Stroobant P, Gwynne D (1993) Glial growth factors are alternatively spliced erbB2 ligands expressed in the nervous system. Nature 362:312-318.

Martin DP, Schmidt RA, DiStephano P, Lowry O, Carter J, Johnson E (1988) Inhibitors of protein synthesis and RNA synthesis prevent neuronal death caused by nerve growth factor deprivation. J Cell Biol $106: 829-844$

Meyer D, Birchmeier C (1995) Multiple essential functions of neuregulin in development. Nature 378:386-390.

Ochoa J (1976) The unmyelinated nerve fiber. In: The peripheral nerve (Landon DN, ed), pp 106-158. London: Chapman and Hall.

Oppenheim RW (1989) The neurotrophic theory and naturally occurring motoneuron death. Trends Neurosci 12:252-255.

Oppenheim RW (1991) Cell death during development of the nervous system. Annu Rev Neurosci 14:453-501.

Oppenheim RW, Chu-Wang I-W, Maderdrut JL (1978) Cell death of motoneurons in the chick embryo spinal cord. III. The differentiation of motoneurons prior to their induced degeneration following limb-bud removal. J Comp Neurol 177:87-112.

Oppenheim RW, Prevette D, Tytell M, Homma S (1990) Naturally occurring and induced neuronal death in the chick embryo in vivo requires protein and RNA synthesis: evidence for the role of cell death genes. Dev Biol 138:104-113.

Peters A, Palay S, Webster HdeF (1976) The cellular sheaths of neurons. In: The fine structure of the nervous system: the neurons and supporting cells, pp 181-230. Philadelphia: W.B. Saunders.

Pittman R, Oppenheim RW, Chu Wang IW (1978) Beta-bungarotoxin induced neuronal degeneration in the chick embryo spinal cord. Brain Res 153:199-204.

Raff MC, Barres BA, Burne JF, Coles HS, Ishizani Y, Jacobson MD (1993) Programmed cell death and the control of cell survival: lessons from the nervous system. Science 262:695-700.

Rajdev S, Reynolds IJ (1994) Glutamate-induced intracellular calcium changes and neurotoxicity in cortical neurons in vitro: effect of chemical ischemia. Neuroscience 62:667-679.

Rowan EG, Harvey AL (1988) Potassium channel blocking actions of $\beta$-bungarotoxin and related toxins on mouse and frog motor nerve terminals. Br J Pharmacol 94:839-847.

Siman R, Card JP (1988) Excitatory amino acid neurotoxicity in the hippocampal slice preparation. Neuroscience 26:433-447.

Sonnenfeld MJ, Jacobs JR (1995) Apoptosis of the midline glia during Drosophila embryogenesis: a correlation with axon contact. Development 121:569-578.

Stewart GR, Olney JW, Pathikonda M, Snider WD (1991) Excitotoxicity in the embryonic chick spinal cord. Ann Neurol 30:758-766.

Trachtenberg JT, Thompson VJ (1996) Schwann cell apoptosis at developing neuromuscular junctions is regulated by glial growth factor. Nature 379:174-177.

Varon S, Bunge RP (1978) Trophic mechanisms in the peripheral nervous system. Annu Rev Neurosci 1:327-361.

Webster HdeF, Martin JR, O'Connell MF (1973) The relationships between interphase Schwann cells and axons before myelination: a quantitative electron microscopic study. Dev Biol 32:401-416. 